\title{
Meningkatkan hasil belajar peserta didik dengan menggunakan Mobile Learning berbasis Flip Pdf Pro Maker (myflip) \\ (A useful mobile base learning media in the Covid-19 era)
}

\author{
Hadza Min Faddli Robbi, Madziatul Churiyah* \\ Universitas Negeri Malang, Jl. Semarang No. 5 Malang, Jawa Timur, Indonesia \\ *Penulis korespondensi, Surel: madziatul.churiyah.fe@um.ac.id
}

Paper received: 7-6-2021; revised: 21-6-2021; accepted: 28-6-2021

\begin{abstract}
Abstrak
Berdasarkan kondisi dan fenomena saat ini, coronavirus masih menjadi masalah utama dalam berbagai bidang, salah satunya yaitu bidang pendidikan yang menjadi salah satu aspek terdampak masalah tersebut. Penyebaran virus ini terbilang sangat cepat dimana sejak akhir tahun 2019 Coronavirus Disease (Covid-19) telah terjadi masalah kesehatan dan berpengaruh terhadap berbagai kebijakan pendidikan, yang salah satu kebijakannya yaitu dilakukannya pembelajaran secara daring (online), sehingga guru dituntut untuk kreatif mengoptimalkan teknologi dalam kegiatan pembelajaran. Oleh karena itu, penelitian ini bertujuan untuk menghasilkan produk MyFlip berbasis Flip PDF Pro Maker untuk meningkatkan hasil belajar peserta didik. Produk media pembelajaran yang dikembangkan terdapat Tujuh menu dan fitur yang mempermudah penggunaan dalam pengoperasiannya Cakupan materi yang lengkap, serta ukuran file sebesar 53 MB dapat membantu peserta didik dalam meningkatkan hasil belajar peserta didik. Penelitian dan pengembangan ini menggunakan model Research and Development Borg and Gall yang telah dimodifikasi. Teknik analisis data yang digunakan adalah deskriptif dan deskriptif persentase. Hasil penelitian dan pengembangan ini adalah MyFlip berbasis Flip PDF Pro Maker pada mata pelajaran Teknologi Perkantoran yang bernama MyFlip yang telah dinyatakan sangat valid dan layak digunakan dalam pembelajaran kearsipan oleh ahli media, ahli materi, dan 6 Peserta Didik uji coba kelompok kecil serta terbukti terdapat perbedaan hasil belajar secara signifikan pada uji coba kelompok besar dimana hasil tes kelas eksperimen lebih tinggi daripada kelas kontrol. Sehingga dapat disimpulkan bahwa MyFlip layak dan efektif digunakan sebagai media pembelajaran untuk meningkatkan hasil belajar Peserta didik pada mata pelajaran Teknologi Perkantoran.
\end{abstract}

Kata kunci: penelitian dan pengembangan; media pembelajaran; mobile learning; flip pdf pro maker; hasil belajar.

\section{Pendahuluan}

Coronavirus Disease (Covid-19) telah menjadi masalah kesehatan dan menggemparkan dunia sejak akhir tahun 2019. Penyebaran virus ini terbilang sangat cepat di Indonesia sejak awal tahun 2020 (Kennedy and Suhendarto, 2020; Krishnamurthy, 2020). Sehingga dalam aspek pendidikan memberlakukan kegiatan Pembelajaran Jarak Jauh (PJJ). Oleh karena itu, dunia pendidikan perlu memanfaatkan kemajuan teknologi dengan melakukan pengembangan media pembelajaran yang diharapkan dapat membantu serta menunjang proses pembelajaran yang lebih baik khususnya pada masa pandemi Covid-19. Secara tidak langsung Siswa tetap melakukan kegiatan pembelajaran secara daring (online) dengan bantuan media pembelajaran yang telah disiapkan oleh guru yang diharapkan kebijakan ini dapat mengurangi penyebaran Covid-19 (Mishra et al., 2020; Ratten and Jones, 2020). Pembelajaran jarak jauh diperlukan media pembelajaran yang tepat dengan memanfaatkan kemajuan dari teknologi agar tujuan pendidikan dapat tercapai (Li et al., 2020; Muhson, 2010). Media pembelajaran sendiri

This work is licensed under a Creative Commons Attribution-ShareAlike 4.0 International License. 
memegang peran penting dalam inovasi proses pembelajaran dimana media pembelajaran mampu membantu guru dalam menyampaikan materi yang diajarkan (Kramer et al., 2020), (Sholihin et al., 2020), (Setyadi \& Qohar, 2017), (Crisp, 2015). Sejalan dengan itu Carter Jr et al (2020) menyampaikan bahwa pembelajaran jarak jauh di masa pandemi seperti sekarang ini, seharusnya lebih mengutamakan kemudahan mengakses materi karena secara psikologi peserta didik dalam kondisi tidak bisa fokus belajar seperti keadaan normal, serta tidak semua peserta didik didampingi oleh orang tua atau orang dewasa lainnya yang dapat membimbing saat pelaksanaan pembelajaran dari rumah. Kemajuan teknologi merupakan sesuatu yang tidak dapat dihindari dari kehidupan, karena kemajuan teknologi berjalan mengikuti kemajuan dari ilmu pengetahuan yang semakin hari akan semakin berkembang, inovasi terbaru akan selalu muncul yang memberikan dampak positif dan manfaat bagi kehidupan manusia (Ngafifi, 2014). Sedangkan Media pembelajaran merupakan perangkat lunak yang berupa informasi pendidikan dan disajikan memakai alat bantu agar pesan atau informasi dapat sampai kepada siswa (Muhson, 2010). Media pembelajaran yang kini mulai beragam mengikuti perkembangan ilmu pengetahuan dan teknologi yaitu media pembelajaran berbasis elektronik yang saat ini telah dijadikan sebagai alternatif pembelajaran di Indonesia dalam melakukan kegiatan belajar dari rumah secara daring, salah satunya yaitu mobile learning.

Pemanfaatan Pembelajaran M-Learning diharapkan memudahkan peserta didik dalam mendapatkan materi yang mudah dipahami dan dikemas menggunakan media smartphone sehingga interaksi antara guru dan siswa tidak terhambat oleh jarak dan waktu dan hasil belajar peserta didik tetap maksimal (Little, 2013, 2012; Nur N. S and Sutarni, 2017; Purwanto and Ramadhan, 2017; Sheng-Hung, 2012). Mobile Learning yang dikembangkan dalam penelitian ini yaitu Mobile Learning berbasis Flip PDF Pro Maker. Media berbasis Flip PDF Pro Maker disajikan dalam bentuk buku yang dapat ditambahkan dengan gambar, video, musik bahkan soal kuis (Fahmi et al. 2019).

Beberapa penelitian sebelumnya yang juga membahas tentang tema ini adalah penelitian (Arini and Kustijono, 2017; Aripin, 2018; Azhary et al., 2020; Divayana et al., 2019; Fahmi et al., 2019; Praseptiawan et al., 2018; Raihan and Ahmadi, 2018; Rasiman and Pramasdyahsari, 2014; Seruni et al., 2020, 2019; Singh et al., 2017; Sriwahyuni et al., 2019; Watin and Kustijono, 2017; Yelianti et al., 2018). berdasarkan penelitian-penelitian tersebut dapat disimpulkan bahwa media pembelajaran mobile learning berbasis flip PDF pro maker yang dapat diakses secara offline dan dapat meningkatkan hasil belajar peserta didik.

Akan tetapi, berdasarkan hasil wawancara guru Mata Pelajaran Teknologi Perkantoran kelas X OTKP. diperoleh informasi bahwa pembelajaran di SMK Negeri 2 Kediri dilakukan secara daring Dan Media pembelajaran yang dimanfaatkan adalah Whatsapp Group. Kondisi ini memaksa guru harus lebih optimal dalam memanfaatkan media pembelajaran untuk menyampaikan materi kepada peserta didik. Pembelajaran daring (dalam jaringan) yang dilakukan juga memiliki kendala karena sulitnya mengakses internet bagi peserta didik yang berada di daerah pelosok desa dan masalah tidak adanya kuota dari peserta didik, membuat presensi peserta didik banyak yang kosong, selain itu waktu pembelajaran yang dipersingkat dari yang awalnya berdurasi 45 menit menjadi 20 menit per satu jam pelajaran juga harus diperhatikan dengan baik oleh guru saat mengajar.Dengan masih adanya kegiatan pembelajaran secara daring dan waktu pembelajaran yang dipersingkat tersebut membuat waktu penyampaian materi yang diberikan pada peserta didik jauh lebih sedikit dan membuat peserta didik masih akan lebih banyak untuk belajar sendiri. Dari masalah tersebut Peneliti 
berinovasi membuat sebuah aplikasi pembelajaran mobile untuk memaksimalkan kondisi yang saat ini terjadi. Peneliti berinovasi membuat sebuah aplikasi Mobile yang bisa diinstall pada handphone peserta didik dan bisa digunakan secara offline pada Mata Pelajaran Otomatisasi Tata Kelola Sarana Dan Prasarana. Aplikasi ini berisikan materi, latihan soal, video pembelajaran sehingga ketika peserta didik tidak ada jadwal pembelajaran secara luring, mereka dapat secara mandiri mempelajari dan mengerjakan latihan soal melalui aplikasi tersebut.

\section{Metode}

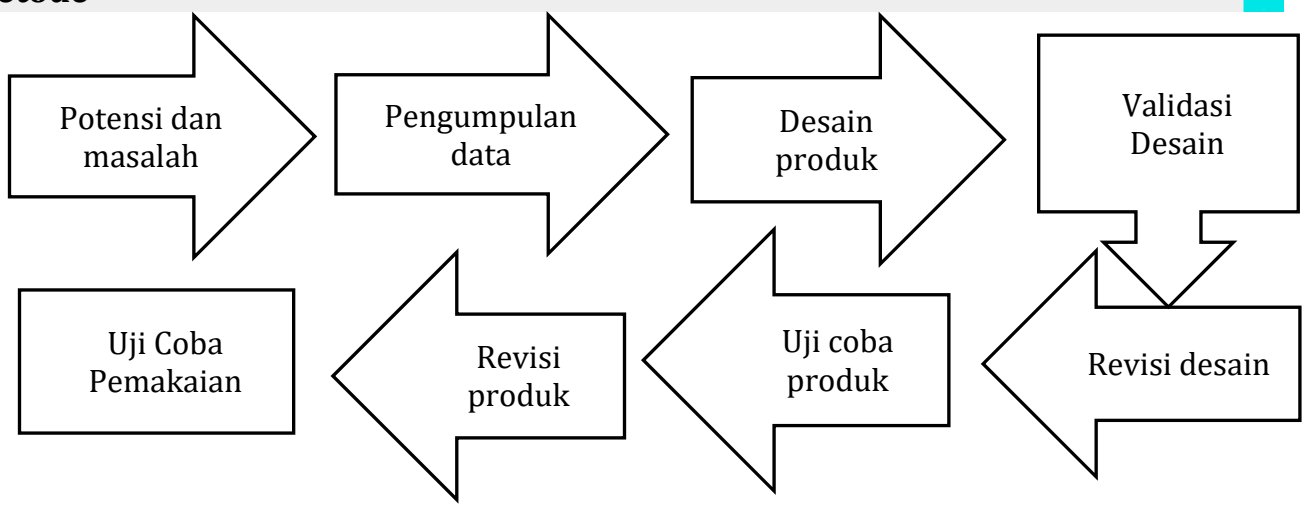

Gambar 1. Langkah-langkah penelitian

Penelitian ini menggunakan model Research and Development Borg and Gall yang telah dimodifikasi menjadi lima langkah untuk mempersingkat waktu dan keadaan lapangan (Ha and Pepin, 2017; Hidayah and Sugiarto, 2015; Ilma and Wijarini, 2017; Kusuma et al., 2018; Mastumasari et al., 2017). Selain itu, peneliti juga merasa bahwa tujuan penelitian yaitu untuk menghasilkan produk, mengetahui kelayakan produk, dan mengetahui perbedaan kemandirian dan hasil belajar peserta didik yang menggunakan dengan yang tidak menggunakan produk yang dikembangkan.

Langkah pertama, peneliti mengumpulkan informasi terkait potensi dan permasalahan yang terjadi di sekolah melalui tahap observasi dan wawancara. Langkah kedua, peneliti mulai merancang produk media pembelajaran yang akan dikembangkan dan disesuaikan dengan kondisi serta kebutuhan untuk mengatasi permasalahan yang ditemukan pada langkah pengumpulan informasi awal. Langkah ketiga, peneliti mulai membuat media pembelajaran sesuai dengan rancangan yang telah ditentukan pada langkah sebelumnya. Langkah keempat yaitu setelah media tersebut dihasilkan maka dilakukan pengujian kelayakan oleh validator, yakni satu ahli media dan satu ahli materi. Langkah kelima, produk yang telah divalidasi direvisi berdasarkan kritik dan saran baik secara tertulis maupun lisan yang tertera pada lembar kuesioner ahli media dan materi. Langkah keenam, produk yang telah direvisi diuji cobakan pada 6 peserta didik kelas X OTKP data ini digunakan untuk memperbaiki atau merevisi media yang dikembangkan sebelum diuji cobakan kepada kelompok besar. Langkah ketujuh, produk yang telah diuji cobakan pada kelompok kecil direvisi sesuai kritik dan saran baik secara tertulis maupun lisan yang tertera pada lembar kuesioner penilaian peserta didik uji coba kelompok kecil. Langkah kedelapan, produk yang telah direvisi dan dinyatakan layak kemudian diuji cobakan pada kelompok besar. Uji coba dilakukan menggunakan kelas X OTKP 1 Selaku kelas eksperimen dan X OTKP 2 selaku kelas kontrol Produk yang telah melewati uji coba kelompok besar menjadi produk akhir dalam penelitian ini. 
Data yang dihasilkan pada penelitian ini meliputi data kualitatif dan data kuantitatif, dimana data data kuantitatif terdiri dari data hasil validasi ahli materi, data hasil validasi media, data hasil uji coba kelompok kecil, dan data hasil belajar peserta didik. Sedangkan data kualitatif didapatkan melalui penarikan kesimpulan berdasarkan saran, dan kritik dari ahli materi, ahli media, dan 6 siswa uji coba kelompok kecil. Data hasil validasi ahli materi, ahli media, dan uji coba kelompok kecil dianalisis menggunakan metode deskriptif persentase untuk menunjukkan tingkat kelayakan media pembelajaran. Sedangkan data hasil belajar peserta didik dianalisis untuk menunjukkan perbedaan hasil belajar peserta didik kelas eksperimen dan kelas kontrol.

\section{Hasil dan Pembahasan}

Produk yang dihasilkan dalam penelitian dan pengembangan ini adalah Mobile Learning berbasis Flip PDF Pro Maker pada mata pelajaran Teknologi Perkantoran. Mobile Learning berbasis Flip PDF Pro Maker (MyFlip) terdiri dari menu yang dijelaskan melalui Gambar 2 berikut ini:

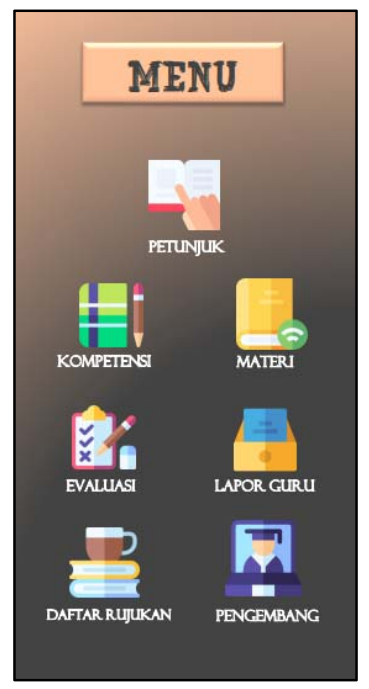

\section{Gambar 2. Menu-menu dalam MyFlip}

Setelah ada di "Halaman Menu", pengguna dapat menuju Halaman Petunjuk seperti pada Gambar 3 yang berisi petunjuk menu yang tersedia. 




Gambar 3. Petunjuk menu aplikasi MyFlip

Hasil validasi MyFlip oleh ahli materi, ahli media, dan siswa uji coba kelompok kecil secara keseluruhan disajikan dalam Tabel 1 berikut ini:

Tabel 1. Data hasil validasi keseluruhan

\begin{tabular}{llll}
\hline No & Validasi & Persentase & Kriteria Validitas \\
\hline 1. & Ahli Materi & $90 \%$ & Sangat Valid \\
2. & Ahli Media & $92 \%$ & Sangat Valid \\
3. & Siswa Uji Coba Kelompok Kecil & $94 \%$ & Sangat Valid \\
& Rata-rata & $\mathbf{9 2 \%}$ & Sangat Valid \\
\hline
\end{tabular}

Table used by permission @ Robbi, Hadza Min Faddli, 2021. Data hasil validasi keseluruhan.

Berdasarkan Tabel 1, diketahui rata-rata persentase validasi secara keseluruhan sebesar 92\%, sehingga dapat disimpulkan bahwa media pembelajaran yang dikembangkan peneliti yakni MyFlip, dinyatakan 'Sangat Valid' dan layak digunakan dalam pembelajaran Teknologi Perkantoran di SMKN 2 Kediri. Hal ini senada dengan penelitian sebelumnya dimana hasil validasi ahli media, ahli materi dan uji coba kelompok kecil sebagai dasar penentuan kelayakan media. (Nardjosoeripto, 2017).

Titik pengukuran berupa validitas mengacu pada hasil pengukuran yang dilakukan untuk mengetahui seberapa banyak aspek dalam ranah kuantitatif pada instrumen pengukuran yang dinyatakan dengan skor (Hendryadi, 2017). MyFlip menyajikan tujuh menu dan fitur yang mempermudah penggunaan dalam pengoperasiannya Cakupan materi yang lengkap, serta ukuran file sebesar 53 MB dapat membantu peserta didik dalam meningkatkan hasil belajar peserta didik. Efisiensi dan penggunaan teknologi yang efektif tergantung pada 
ketersediaan perangkat keras dan perangkat lunak (Afshari et al., 2009; Agbo, 2015; Gandal et al., 2000).

Tampilan hasil analisis data hasil belajar peserta didik antara kelas kontrol dan eksperimen dapat dilihat pada Gambar 3 berikut:

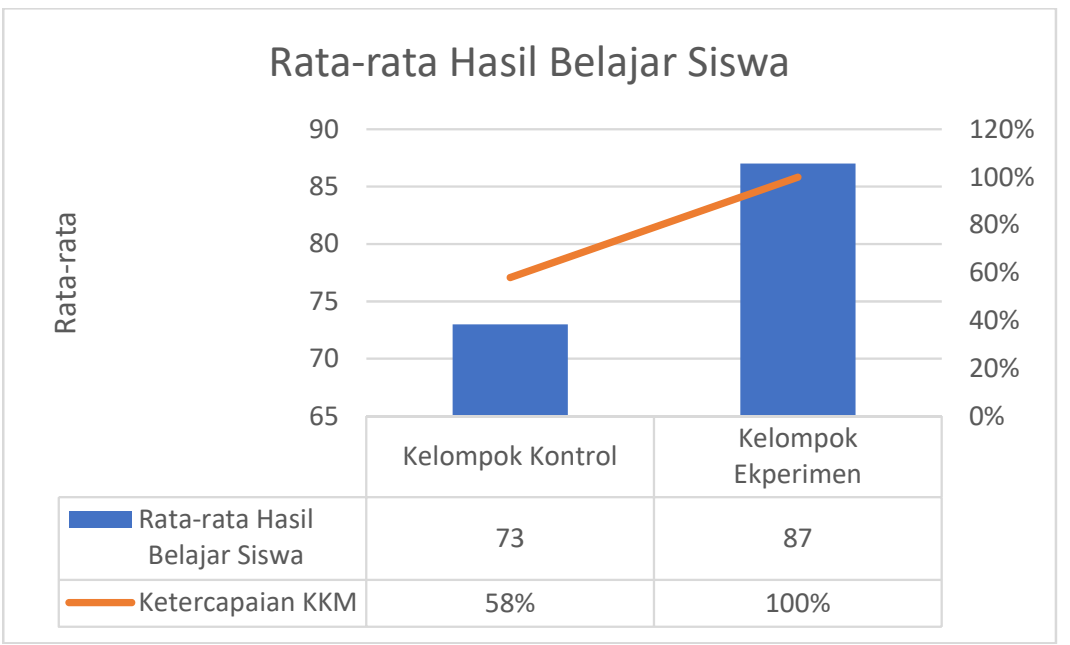

Gambar 4. Rata-rata Nilai Hasil Belajar Peserta Didik

Berdasarkan paparan dalam Gambar 4 tersebut dapat dilihat bahwa hasil perhitungan posttest menunjukkan rata-rata hasil belajar peserta didik kelas eksperimen adalah 87 dan ketercapaian terhadap KKM mencapai $100 \%$ atau seluruh peserta didik memiliki nilai di atas KKM. Sedangkan rata-rata hasil belajar peserta didik kelas kontrol adalah 73 dan ketercapaian terhadap KKM mencapai 58\% atau terdapat empat belas peserta didik yang memiliki nilai di bawah KKM. Hal ini menunjukkan bahwa rata-rata belajar kelas eksperimen lebih tinggi daripada kelas kontrol.

\section{Simpulan}

Penelitian dan pengembangan ini menghasilkan Mobile Learning berbasis Flip PDF Pro Maker pada mata pelajaran Teknologi Perkantoran untuk meningkatkan hasil belajar peserta didik. Media pembelajaran ini bernama MyFlip yang dapat diunduh dan di install melalui link manual https://bit.ly/3du02v6 serta dapat akses secara offline.

Media pembelajaran pada penelitian ini telah dinyatakan 'Sangat Valid' dan layak digunakan dalam pembelajaran Teknologi Perkantoran melalui validasi oleh ahli materi, ahli media serta uji coba kelompok kecil. Selain itu, MyFlip ini disimpulkan bahwa terdapat perbedaan yang relevan dan juga dapat meningkatkan hasil belajar peserta didik pada uji coba kelompok besar. MyFlip ini juga memungkinkan pembelajaran kapanpun dan dimanapun, bahkan secara mandiri tanpa harus terikat dengan kegiatan tatap muka di sekolah, sehingga aplikasi ini berguna ketika pembelajaran tidak dapat dilakukan dengan bertatap muka secara langsung seperti saat terjadi akibat adanya pandemi covid-19.

MyFlip hanya berfokus pada beberapa kompetensi dasar dan terbatas pada sistem operasi android, sehingga diharapkan peneliti selanjutnya mengembangkan media pembelajaran pada sistem operasi lainnya seperti IOS. 


\section{Ucapan Terima Kasih}

Penulis mengucapkan terimakasih kepada Universitas Negeri Malang dan SMKN 2 Kediri yang telah memfasilitasi dan memberi izin kepada peneliti untuk melakukan kegiatan penelitian dan pengembangan ini.

\section{Daftar Rujukan}

Afshari, M., Bakar, K.A., Luan, W.S., Samah, B.A., Fooi, F.S., (2009). Factors Affecting Teachers' Use of Information and Communication Technology. International Journal of Instruction 2(1), 77-104.

Agbo, I.S., (2015). Factors Influencing the Use of Information and Communication Technology (ICT) in Teaching and Learning Computer Studies in Ohaukwu Local Government Area of Ebonyi State-Nigeria. Journal of Education and Practice 6(7). http://iiste.org/Journals/index.php/JEP/article/view/20674/21262

Arini, D., Kustijono, R., (2017). The Development Of Interactive Electronic Book (Budin) Using Flip Pdf Professional To Train Higher Order Thinking Skills. Jurnal Inovasi Pendidikan Fisika 06, 7.

Aripin, I., (2018). Konsep dan Aplikasi Mobile Learning Dalam Pembelajaran Biologi. Jurnal Bio Educatio 3(1) 01-09.

Azhary, S., Suryadarma, G., Devitasari, P., Kuswanto, K., (2020). Development of Science E-Flipbook Integrated Illegal Sand Mining on River Basin to Improve Environmental Care Attitude. IJECA 3. https://doi.org/10.31764/ijeca.v3i1.2036

Carter Jr, R.A., Rice, M., Yang, S., Jackson, H.A., (2020). Self-regulated learning in online learning environments: strategies for remote learning. ILS 121, 321-329. https://doi.org/10.1108/ILS-04-2020-0114

Crisp, N., (2015). Co-Development, Innovation And Mutual Learning - Or How We Need To Turn The World Upside Down. Healthcare 3, 221-224. Https://Doi.Org/10.1016/J.Hjdsi.2015.06.002

Divayana, D.G.H., Suyasa, P.W.A., Ariawan, I.P.W., Mahendra, I.W.E., Sugiharni, G.A.D., (2019). The Design of Digital Book Content for Assessment and Evaluation Courses by Adopting Superitem Concept Based on Kvisoft Flipbook Maker in era of Industry 4.0. J. Phys.: Conf. Ser. 1165, 012020. https://doi.org/10.1088/1742-6596/1165/1/012020

Fahmi, S., Priwantoro, S.W., Cahdriyana, R.A., Hendroanto, A., Rohmah, S.N., Nisa, L.C., (2019). Interactive Learning Media Using Kvisoft Flipbook Maker for Mathematics Learning. J. Phys.: Conf. Ser. 1188, 012075. https://doi.org/10.1088/1742-6596/1188/1/012075

Firdausi, R., Santosa, A.B., (2016). Pengembangan Media Pembelajaran Mobile Learning Berbantuan Smartphone Android pada Mata Pelajaran Perekayasaan Sistem Antena Studi pada Siswa Kelas XI TAV Smk Negeri 1 Nganjuk. Jurnal Pendidikan Teknik Elektro 05, 7.

Gandal, N., Kende, M., Rob, R., (2000). The Dynamics of Technological Adoption in Hardware/Software Systems: The Case of Compact Disc Players. The RAND Journal of Economics 31, 43-61. https://doi.org/10.2307/2601028

Ha, L., Pepin, J., (2017). Experiences of nursing students and educators during the co-construction of clinical nursing leadership learning activities: A qualitative research and development study. Nurse Education Today 55, 90-95. https://doi.org/10.1016/j.nedt.2017.05.006

Hendryadi, H., (2017). Validitas Isi: Tahap Awal Pengembangan Kuesioner. Jurnal Riset Manajemen dan Bisnis 2, 169-178. https://doi.org/10.36226/jrmb.v2i2.47

Hidayah, I., Sugiarto, (2015). Model of Independent Working Group of Teacher and its Effectiveness towards the Elementary School Teacher's Ability in Conducting Mathematics Learning. Procedia - Social and Behavioral Sciences 214, 43-50. https://doi.org/10.1016/j.sbspro.2015.11.591

Ilma, S., Wijarini, F., (2017). Developing of environmental education textbook based on local potencies. JPBI 3, 194-201. https://doi.org/10.22219/jpbi.v3i3.4540

Kennedy, R., Suhendarto, B.P., (2020). Diskursus Hukum: Alternatif Pola Pengisian Jabatan Kepala Daerah di Masa Pandemi Covid-19. Jurnal Pembangunan Hukum Indonesia 2, 188-204. https://doi.org/10.14710/jphi.v2i2.188-205

Kramer, C., König, J., Strauß, S., Kaspar, K., (2020). Classroom Videos or Transcripts? A Quasi-Experimental Study To Assess The Effects Of Media-Based Learning On Pre-Service Teachers' Situation-Specific Skills Of Classroom Management. International Journal of Educational Research 103, 101624. Https://Doi.Org/10.1016/J.Ijer.2020.101624 
Krishnamurthy, S., (2020). The future of business education: A commentary in the shadow of the Covid-19 pandemic. Journal of Business Research 117, 1-5. https://doi.org/10.1016/j.jbusres.2020.05.034

Kusuma, E.D., Gunarhadi, G., Riyadi, R., (2018). The Development of Problem-Based Quantum Learning Model in Elementary Schoolin. International Journal of Educational Research Review 3, 9-16. https://doi.org/10.24331/ijere.412267

Li, J., Sheng, J., Chen, Y., Ke, L., Yao, N., Miao, Z., Zeng, X., Hu, L., Wang, Q., (2020). A Web-Based Learning Environment of Remote Sensing Experimental Class with Python. Int. Arch. Photogramm. Remote Sens. Spatial Inf. Sci. XLIII-B5-2020, 57-61. https://doi.org/10.5194/isprs-archives-XLIII-B5-2020-57-2020

Little, B., (2013). Issues in mobile learning technology. Hum Res Mgt Intl Digest 21, 26-29. https://doi.org/10.1108/09670731311318361

Little, B., (2012). Effective and efficient mobile learning: issues and tips for developers. Ind and Commercial Training 44, 402-407. https://doi.org/10.1108/00197851211267983

Mastumasari, I., -, W., -, S., (2017). Improving Learning Outcomes in Office Automation Subjects through Development of Video-Based Media Learning Operating Microsoft Publisher 2010. JPBM Ournal Pendidikan Bisnis dan Manajemen) 3, 55-64. https://doi.org/10.17977/um003v3i12017p055

Mishra, L., Gupta, T., Shree, A., (2020). Online teaching-learning in higher education during lockdown period of COVID-19 pandemic. International Journal of Educational Research Open 100012. https://doi.org/10.1016/j.ijedro.2020.100012

Motiwalla, L.F., (2007). Mobile learning: A framework and evaluation. Computers \& Education 49, 581-596. https://doi.org/10.1016/j.compedu.2005.10.011

Muhson, A., (2010). Pengembangan Media Pembelajaran Berbasis Teknologi Informasi. Jurnal Pendidikan Akuntansi Indonesia 8. https://doi.org/10.21831/jpai.v8i2.949

Ngafifi, M., (2014). Kemajuan Teknologi Dan Pola Hidup Manusia Dalam Perspektif Sosial Budaya. Jurnal Pembangunan Pendidikan: Fondasi dan Aplikasi 2. https://doi.org/10.21831/jppfa.v2i1.2616

Praseptiawan, M., Sujana, D., Djuanda, M., (2018). Pengembangan Mobile Learning (M-Learning) Stkip Setiabudhi Sebagai Daya Dukung Pembelajaran Mahasiswa. Jurnal Produktif 2.

Purwanto, P., Ramadhan, A.N., (2017). Pengembangan dan Unjuk Kerja Sistem Kearsipan Elektronik PSPAP. Efisiensi - Kajian Ilmu Administrasi 13, 31-65. https://doi.org/10.21831/efisiensi.v13i2.11676

Putra, K.W.B., Wirawan, I.M.A., Pradnyana, G.A., (2017). Pengembangan E-Modul Berbasis Model Pembelajaran Discovery Learning Pada Mata Pelajaran "Sistem Komputer" Untuk Siswa Kelas X Multimedia Smk Negeri 3 Singaraja. Jurnal Pendidikan Teknologi dan Kejuruan 14.

Raihan, S., Ahmadi, F., (2018). Development of Scientific Learning E-Book Using 3D Pageflip Professional Program. Innovative Journal of Curriculum and Educational Technology $7,8$. https://doi.org/10.15294/ijcet.v7i1.24793

Rasiman, Pramasdyahsari, A.S., (2014). Development of Mathematics Learning Media E- Comic Based on Flip Book Maker to Increase the Critical Thinking Skill and Character of Junior High School Students. International Journal of Education and Research 2, 10. https://www.ijern.com/journal/2014/November-2014/44.pdf

Ratten, V., Jones, P., (2020). Covid-19 and entrepreneurship education: Implications for advancing research and practice. The International Journal of Management Education 100432. https://doi.org/10.1016/j.ijme.2020.100432

Saeroji, A., (2014). Inovasi Media Pembelajaran Kearsipan Electronik Arsip (E-Arsip) Berbasis Microsoft Office Access. Jurnal Dinamika Pendidikan 9. https://doi.org/10.15294/dp.v9i2.4893

Seruni, R., Munawaroh, S., Kurniadewi, F., Nurjayadi, M., (2020). Implementation of e-module flip PDF professional to improve students' critical thinking skills through problem based learning. J. Phys.: Conf. Ser. 1521, 042085. https://doi.org/10.1088/1742-6596/1521/4/042085

Setyadi, D., Qohar, A., (2017). Pengembangan Media Pembelajaran Matematika Berbasis Web Pada Materi Barisan Dan Deret. Kreano, Jurnal Matematika Kreatif-Inovatif 8, 1-7. Https://Doi.Org/10.15294/Kreano.V8i1.5964

Sheng-Hung, C., (2012). Course delivery and module learning via learning objects (knowledge map) in mobile learning environment. Asian Assoc Open Uni Jrnl 7, 43-54. https://doi.org/10.1108/AAOUJ-07-012012-B004 
Jurnal Ekonomi, Bisnis dan Pendidikan, 1(6), 2021, 517-525

Sholihin, M., Sari, R.C., Yuniarti, N., Ilyana, S., (2020). A New Way of Teaching Business Ethics: The Evaluation Of Virtual Reality-Based Learning Media. The International Journal of Management Education 18, 100428. Https://Doi.Org/10.1016/J.Ijme.2020.100428

Singh, A.A.G., Leavline, E.J., Selvam, J., (2017). Mobile Application for m-Learning. International Journal of Advanced Research in Computer Science 8.

Subari, A., Tadeus, D.Y., Winarno, H., Yuwono, T., (2018). Rancang Bangun Sistem Administrasi Kerja Praktek Dan Tugas Akhir Berbasis Web Menggunakan Framework Codeigniter. Gema Teknologi 19, 1. https://doi.org/10.14710/gt.v19i4.19147

Tabuenca, B., Kalz, M., Drachsler, H., Specht, M., (2015). Time will tell: The role of mobile learning analytics in self-regulated learning. Journal of Computers \& Education 89, 53-74. https://doi.org/10.1016/j.compedu.2015.08.004

Yelianti, U., Muswita, M., Sanjaya, M.E., (2018). Development of Electronic Learning Media Based 3D Pageflip on Subject Matter of Photosynthetis in Plant Physiology Course. BIO 4, 121-134. https://doi.org/10.22437/bio.v4i2.5858 